\title{
Industrial Harmony and Employee Performance in Food and Beverage Firms in Anambra State of Nigeria
}

\author{
Dr. Chinedu Uzochukwu Onyeizugbe ${ }^{1}$, Dr. Vincent Aghara ${ }^{2}$, Dr. Enaini Stella Olohi ${ }^{3}$, \\ Abaniwu Perpetual Chidiogo ${ }^{4}$ \\ ${ }^{1,4}$ Department of Business Administration, Nnamdi Azikiwe University, Awka, Nigeria \\ ${ }^{2}$ Department of Marketing, Nnamdi Azikiwe University, Awka, Nigeria \\ ${ }^{3}$ Department of Business Administration, Auchi Polytechnic, Auchi, Edo State, Nigeria
}

*Corresponding Author: Dr. Chinedu Uzochukwu Onyeizugbe, Department of Business Administration, Nnamdi Azikiwe University, Awka, Nigeria

\begin{abstract}
The non-existence of a pure state of industrial harmony, management practice of exclusionism, and derogation of organizational communication pattern among food and beverage firms in Anambra state have led to grievance between employees and management which has eroded the set objectives of these firms. This study seeks to determine the extent of relationship that exists between industrial harmony and employee performance in selected Food and Beverage Firms in Anambra state while specifically the study seeks to ascertain the extent of relationship that exists between joint consultation and employee engagement in selected Food and Beverage Firms in Anambra State, and to determine the extent of relationship that exists between industrial democracy and employee loyalty in selected Food and Beverage Firms in Anambra State. The study employed correlation survey research design. The population of the study was 390 employees of five selected Food and Beverage Firms in Anambra State, Pearson product moment correlation was used to analyze the data collected. The findings revealed that there is a very strong significant positive relationship between joint consultation and employee engagement, and there is a very strong positive relationship between industrial democracy and employee performance. The study concluded that industrial harmony plays a crucial role in determining employee performance in selected Food and Beverage Firms in Anambra State and recommended that management of the focused firms should give room for unions in the organizations to air their views and try as much as possible to align the needs of the employees to that of the organization, management of the focus organizations should create an atmosphere of feeling of belonging by allowing the employees to participate in decision making on matters that relate to them.
\end{abstract}

Keywords: Industrial Harmony, Joint Consultation, Industrial Democracy, Employee Performance, Employee Engagement, Employee Loyalty

\section{INTRODUCTION}

Industrial Harmony constitutes one of the most delicate and complex problems of the modern industrial society. This phenomenon of a new complex industrial set-up is directly attributed to the emergence of "Industrial Revolution". The pre-industrial revolution period was characterized by a simple process of manufacturing, small scale investment, local markets and small number of persons employed which resulted to a close relationship between the manager and the managed. Due to personal and direct relationship between the employer and the employee it was easier to secure cooperation among employees in organizations. Any grievance or misunderstanding on the part of either party could be promptly removed. Also, there was no management interference in the economic activities of the employees. Within this period, industrial relations were simple, direct and personal. This situation underwent a remarkable change which resulted to the advent of industrial revolution. The size of the business increased requiring enormous investment on financial and human resources. There emerged a new class of professional managers causing divorce between ownership and management, and relations between the employer and the employee became estranged and gradually antagonistic. This new set-up rendered the old philosophy of industrial relation irrelevant and gave rise to complex, indirect, and impersonal industrial relations.

The challenge of modern day business is the increased awareness on the part of employees about their rights and privileges. Izidor (2015) asserts that the rise in this awareness has become a pain in the 
neck of growing management to such concerns that it attempts to diminish the glory of capitalistic mindedness that once bestride the pathway to managing like a colossus. Industrial harmony in most organizations seems to be affected by this development that the frequency of management-employee conflicts is fast raising among organizations. These types of conflict prevent the existence of industrial harmony which reflect a state of organizational instability (Sayles and Strauss, 2009). The Nigeria workplace context had for decades been embattled in the demands for increased concern on issues that relate to employer-employee relationship which is a form of motivation.(Akinwade, 2011).

In recent times, industrial disharmony is assuming unprecedented proportion in most of the food and beverages firms in Nigeria. The incessant grievance and conflicts between management and employee in food and beverage industry has more than ever before been publicized in the manifestation of negative consequences such as decline in the performance of organization and that of the employee (Agba, Ushie; \& Agba, 2009). Albert and Yahaya (2013) lent credence to this view, that the pattern of industrial relations in Nigeria has been conflictual in nature with disruptive consequences and significant work-stoppages. Various reasons and explanations have been adduced as to why the relationship between labour and management is conflict ridden. Arguably, it is observed that management of food and beverage firms in Anambra State practice management of exclusionism, neglect of power sharing mechanism which ensure partnership amongst stakeholders in the workplace and derogation of organizational communication pattern may breed disharmony in contemporary organizations (Iheriohanma, 2007).

Consequently, labour and management, as well as owners of means of production have developed a web of rules to govern their day-to-day interactions so as to promote harmonious relationship between them (Dunlop, 1958). Different conflict handling mechanisms have also been developed to minimize the occurrence and reoccurrence of industrial disharmony in the focused firms. In these firms, collective bargaining, work-floor democracy and other grievance management procedures were introduced to induce industrial harmony. Despite these innovations, industrial disputes seem to be assuming unprecedented level in these organizations.

A pure state of industrial harmony scarcely exists in the food and beverage industry in Anambra state, as grievance between employees and management erodes the set objectives of the organizations. It seems the Managers of these organizations believe too much in their ability and ego, it seems they believe in dishing out orders, directives and policies to the workers, they failed to involve employees in all policy process. In some cases they make decisions not minding its implication on the people who are to implement them. Social relations in these firms are creamed in master servant power chain to such an extent that the employee has no close ties with the owners of work, or its agents. Orders are given using the steam shovel approach such that no one worker is allowed to know the reason for any decision that affects the tasks they do (Nkiinebari, 2014). Employee working in such organizational climate may feel dissatisfied as the managements of this organization are only concerned about the organization and not considering how the employee feels. Such organizational culture breeds disharmony between management and employee. These seem to lead to low employee engagement, loyalty and employee satisfaction in the organization. Iheriohanma (2007) asserts that management practice of exclusionism, neglect of power sharing mechanism which ensures partnership amongst stakeholders in the workplace and derogation of organizational communication pattern may breed disharmony in contemporary organizations.

Probably, the conditions of employment, have been inadequate with respect to the area of job security, redundancy, health, welfare and safety of workers are not favourable to the employee. As most of the employees complained that their hard work and commitment are not always put into consideration when the organization wants to downsize rather the management attach some elements of organizational politics. In the area of health, welfare and safety of workers the policy are made in favour of the organization and management are not committed to it. Numerous firms in Nigeria are tormented by a bunch of issues created by wasteful and incapable administrative style or strained relationship amongst administration and the worker's party (Fapohunda, 2012). These may have led to employees exhibiting such attitudes as lack of cooperation and withdrawal attitude of the employees in the place of work, reduced commitment and increased intent to leave by employees. Other visible symptoms are bad tempered behaviour and appearance, moodiness, worry and tension, insubordination, increase in wastage and decline in productivity of the worker who indulges in self 
criticism, develops negativism and in extreme cases tries to destroy the valuable property of the organization. In the end, the focused firms performance suffer as employees whose intention is to leave at every given opportunity may not put in their best in the organization as the loyalty of such an employee may not lie with the organization. This could be responsible for delayed production, increase in equipment breakdown and excess expenditure in replacing and training new employees. Despite the immense contribution of food and beverage firms to the growth of Nigerian Economy and Anambra State in particular, through the creation of employment, income generation for government, tax, GDP and food security, the potentials inherent in this industry appear thwarted by the nature of industrial harmony in these organizations. It is against this backdrop that this study seeks to ascertain the extent to which industrial harmony relates to employee performance in selected food and beverages in Anambra State of Nigeria.

\subsection{Objective of the Study}

The broad objective of the study is to determine the extent of relationship that exists between industrial harmony and employee performance in selected food and beverage firms in Anambra state while specifically the study seeks to:

- Determine the extent of relationship that exists between industrial democracy and employee loyalty in selected Food and Beverage Firms in Anambra State Nigeria.

\subsection{Research Question}

- To what extent does industrial democracy relates to employee loyalty in selected Food and Beverage Firms in Anambra State Nigeria?

\subsection{Research Hypothesis}

- There is a significant relationship between industrial democracy and employee loyalty in selected Food and Beverage Firms in Anambra State Nigeria.

\section{REVIEW OF RELATED LITERATURE}

\subsection{Industrial Harmony}

Industrial harmony refers to a friendly and cooperative agreement on working relationships between employers and employees for their mutual benefit (Otobo, 2005; Osad and Osas, 2013). According to Puttapalli and Vuram (2012), industrial harmony is concerned with the relationship between management and employees with respect to the terms and conditions of employment and the work place. In effect, it is a situation where employees and management cooperate willingly in pursuit of the organization's aims and objectives.

Industrial harmony in its ideal form, presupposes an industry in a condition of relative equilibrium where relationship between individuals and or groups are cordial and productive. Sayles and Strauss (1981) assert that with the inevitable differences among groups within an organization, conflict and differing objectives permeate modern organizations. This type of conflict prevents the existence of industrial harmony which reflects a state of organizational instability (Sayles and Strauss, 2009). On the other hand, Hanson (2006) opines that industrial harmony represents absence of strike by industrial unions in organization which is bound to result in effective and efficient organization.

Industrial harmony thus covers four broad areas of cooperation: responsibilities, employment policy, collective bargaining, communication and consultation (Odia and Omofonmwan, 2007). Industrial Harmony can only come out of what is known as "Industrial Democracy" a situation in organisation where to a larger extent, the participation of workers is adequately sought in the process of making decisions that will determine the conditions of their working lives. It involves joint participation in decision making process between the two major actors to labour relations. It encompasses such concepts as joint consultation, co-ownership or co-partnership, co-determination and whiltleyism (Otobo 2005). Industrial harmony enhances labour productivity and in turn improves performance in organizations, achieving economic growth, and enhancing living standards and quality of life. It creates a peaceful working environment conducive to tolerance, dialogue and other alternative (to strike) means of resolving industrial or labour disputes in Nigeria (such as negotiation, mediation, arbitration, conciliation and litigation or court adjudication). This creates a high level of employee satisfaction. 


\subsubsection{Industrial Democracy}

Industrial democracy is a term generally used to argue that, by analogy with political democracy, workers are entitled to a significant voice in the decisions affecting the organizations in which they work.( Fejoh 2015). The term is not used in a consistent manner as it is also used by some workers to argue that any system short of full workers' control is a denial of industrial democracy and this was the standpoint adopted by union activists in the early decade of the century who advocated a form of guild socialism which was a form of workers' control of industrial organizations. (Fejoh, 2015).

In any human society, there must be leaders and followers. In work organization however, it is the management and labour and as related to power distribution and structures between the levels. Max Weber (1947) in his classical theory said that power flow from the super-ordinates to the subordinates. Laosebikan (1995) said "all", as being used to refer to both employers and employees never means equality in status and power but simply in formulation and designing cum execution of policies which has been jointly agreed upon. Industrial democracy is accepted as the same as workers' participation in management and it is a form of labour-management relations.

Clegg (1960) confronted us with a radically reductive new approach to industrial democracy. $\mathrm{He}$ defines industrial democracy as a mechanism that provides the protecting of the rights and safeguarding the interests of industrial workers. Advocating a model of pure and simple trade unionism he asserted that there is no effective alternative to collective bargaining as a means of protecting the interests and rights of workers. While expatiating on the level and forms of workers participation in management, Averineni (2012) submitted that workers' participation is possible at all levels of management. He however added that the only difference is that of degree and nature of application which may be vigorous at lower level and faint at top level.

\subsubsection{Employee Performance}

The most important dependent variable is the employees' performance (Borman, 2004). According to Sinha (2001), employees' performance is dependent on the willingness and the openness of the employees in doing their job. Further he stated that by having this willingness and openness of the employees in doing their job, it could increase the employees' productivity which also leads to the performance. An employee's performance can also be determined as a person's ability to perform also including the opportunity and willingness to perform as well. The meaning of willingness to perform means that the desire of the employees in putting as much effort towards their job (Eysenck, 1998).

\subsubsection{Employee Loyalty}

Loyalty, as a general term, signifies a person's devotion or sentiment of attachment to a particular object, which may be another person or group of persons, an ideal, a duty, or a cause. It expresses itself in both thought and action and strives for the identification of the interests of the loyal person with those of the object" (Encyclopedia Britannica, 1998).

Employee loyalty could be defined as a psychological inclination, a "feeling" of identification with, an attachment or a commitment to the organization (Guillon \& Cezanne, 2014). It is an observable workplace phenomenon materialized in staying in the organization over the long term that encompasses a little tendency to seek or examine outside job offers (Guillon \& Cezanne, 2014). Loyalty integrates as well a strong desire to continue membership of an organization (Turkyilmaz et al., 2011), living and standing up to the vision and values of the organization (Davis, 2015; Durking, 2007), investing high levels of efforts for the sake of the organization (Becker, Randal \& Riegel, 1995 after Turkyilmaz et al., 2011), or even a willingness to work late (Guillon \& Cezanne, 2014). Companies clearly understand that loyal employees make them solid and profitable and that happy but disgruntled (thus, disloyal) employees have the opposite effect (Durkin, 2007). The employee loyalty has been proven to create value for organizations (Guillon \& Cezanne, 2014) through higher levels of effort and contribution provided, better product quality, better service, higher levels of consumer satisfaction, increased profits, greater shareholder value, increased organizational reputation, and lower turnover rates/costs (see Davis, 2015; Durkin, 2007; Duboff \& Heaton, 1999; Guillon \& Cezanne, 2014; Ibrahim \& Al Falasi, 2014; Silvestro, 2002). On the other side, a lack of loyalty can clearly be detrimental and result 


\subsection{Theoretical Framework}

Theoretical framework of this research is the Conflict Management Theory Propounded by Mary Parker Follett (1933). She holds the view that conflict is inevitable in all organizations or societies where two or more people are brought together to achieve a pre-determined end. She explains that conflict is simply an exhibition of differences in ideas or opinions on given situations. Conflict could also be a display of different methodology of interpreting phenomena. Conflict to her arises as a result of different approaches to issues or different approaches to existing conflict resolutions. She opined that conflict could be good or bad or neither good or nor bad depending on the situation. Conflict also provides good or bad results or outcome depending on the manners it is interpreted, understand and resolved by the affected parties. In an article entitled "Constructive Conflict" she noted that three different ways or methods of conflict resolution; domination, compromise, and integration.

The relevance of this theory (conflict management) is the fact that food and beverage firms consist of people who come together with the aim of achieving a given objective, as such conflict is inevitable in such a situation. Since, both players would want to achieve its individual or group objective in such given situation conflict of interest may arise which if not properly handled might result to industrial conflict.

Using the integration approach by the management will bring about the expected industrial harmony in these organizations. This is because, the divergent interest or demands of these actors are critically analyzed put forward for discussion, usually in a roundtable conference with the aim coming out with lasting solution to the cause(s) of conflicts. Conflict resolved in this fashion (integration approach) is constructive because each side is fully satisfied win-win situation. This integration method is in line with collective bargaining principle, which is the process of negotiations between employers and the representatives of a unit of employees aimed at reaching agreements that regulate working conditions. This by will create room for employee commitment, employee loyalty and employee innovativeness in these organizations.

\subsection{Empirical Review}

Okon, Asu, Patrick and Antigh (2012) carried out a study to determine the impact of inter-union conflicts on industrial harmony. University of Calabar Teaching Hospital and Federal NeuroPsychiatric Hospital Calabar were the only tertiary health institutions in Nigeria's Cross River State and the 2575 total staff strength of the two organizations was the study population. A total of 266 subjects was randomly sampled. Pearson Product Moment Correlation test was conducted to test the null hypothesis and it was established that there was significant influence of inter-union conflicts on industrial harmony in the study case. Recommendations to reduce the inter-union conflicts and enhance industrial harmony include, among others, the removal of salary disparity among unions, and the review of law and working conditions.

Moorthy (2005) carried out a study on industrial relations scenario in Textile Industry in Tamil Nadu. The paper attempted to identify the changes that have occurred in industrial relations scenario in textile industry in Tamil Nadu after the economic reforms introduced during the nineties. The study concluded that economic reforms have affected industrial relations in textile industry in Tamil Nadu as there is a declining tendency in industrial disputes. The prevailing atmosphere of labour unrest could be attributed to total violation of certain norms of discipline by a section of trade unions and also by some employers.

Mojaye and Dedekuma (2015) conducted a study on the influence of communication on Industrial Harmony in the Civil Service of Delta State Nigeria. The study tries to establish a link between communication and good industrial relations and industrial peace. The study focused on the Delta State Civil Service and attempted to find out the role that effective communication had played in ensuring industrial peace since the advent of the state. Questionnaires were administered to 325 civil servants out of which only 299 were useful. One of the research questions was whether there is any relationship between industrial harmony and effective communication. The study showed that while effective communication may not necessarily lead to good industrial relations but it may engender industrial peace.

Nkiinebari (2014) conducted a study on workplace democracy and industrial harmony in Nigeria. This study seeks to unravel the immediate causes of this workplace social distance. In an effort to 
provide the antidote for workplace cooperation, selected manufacturing firms in Port Harcourt Nigeria were studied. The population consisted of 588 workers of selected manufacturing firms in Port Harcourt and the sample size determined using the Krejcie and Morgan (1970) sample size table was 234. For data analysis, frequencies and descriptives were used, the use of percentages, mean scores and standard deviations were used alongside linear regression to examine the relationship between Workplace democracy and Industrial harmony. The study revealed that there is a high prevalence of tall structured organization which creates a gap between labour and management, thus mutual cooperation seemed not to be existing. Qualitative and quantitative methods were used in gathering and analyzing the data and recommendations were obvious that some mutual conditions among which due process, voting and collective bargaining are palliative agents capable of reducing the evident relationship strain between labour and management which have frequently resulted in strikes as the extremes.

Idowu (2012) investigated the impact of workers` training programmes on industrial strike reduction among industrial workers in Nigeria. The purpose of the study is to ascertaining the relevance of workers` training programmes, as an alternative approach to human capital formation, to industrial strike reduction among industrial workers in Nigeria. A total of 230 respondents were selected for the study using stratified sampling technique to reflect the two strata of public and private organizations. Two sets of questionnaire, with three subscales, titled 'Workers Training Programmes Scale (WTPS) and Industrial Strike Reduction Scale (CRS) were used for data collection. All the hypothesized research questions were examined using Regression Analysis and t-test statistical methods at 0.05 alpha levels. The finding revealed that workers` training programmes (taken together) had significantly influenced industrial strike reduction among industrial workers. It was also found that only three independent variables (conflict skill, communication skill and interpersonal relations skill training programmes) have significantly influenced industrial strike reduction. However, it was found that management skill and computer skill training programmes were not as significant in influencing industrial strike reduction in selected work organizations. Also, there was no significant difference in the level of female and male workers` participation in workers` training programmes in both public and private organizations selected for the study.

Ukonu, and Gideon (2016) investigated the role of national industrial court in sustaining harmony in Nigerian health sector: a case of university of Abuja teaching hospital. The main objective is to examine the role National Industrial Court (NIC) has played in sustaining harmony in Nigeria health sector while the specific objective is to examine the role National industrial Court has previously played and can still play futuristically to enhance the desired industrial harmony in University of Abuja Teaching Hospital, the entire health sector and other sectors of the economy. This study concludes, that the role of National Industrial Court in sustaining industrial/organisational harmony especially in the health sector cannot be over emphasised. Basically, industrial harmony is requisite to economic growth, development and industrial advancement in any economy. As such, whether in the instances of inter union disputes or in the demesnes of employee and employer relationship, NIC has risen to the challenge to extinguish the rising tensions that might have escalated out of proportion in UATH as well as other institutions.

Nkiinebari (2015) studied employee engagement and workplace harmony in Nigeria Civil Service. The study attempted to examine the extent to which employee engagement as a non-financial incentive can significantly influence the degree of workplace harmony in the Nigeria civil service. Samples of 400 employees were randomly drawn from 10 ministries in the Rivers State Civil Service, Nigeria. Structured questionnaire items were administered on the sampled respondents and data gathered were tested using the Pearson Product Moment Correlation statistics for relationship in the hypothesis one as well as the independent T-Test analysis for test of influence of the hypothesis two. Results revealed a significant relationship and influence of the variables of employee engagement on workplace harmony in the studied sector. The results culminated into our condition that employee engagement is a critical non-financial incentive that has significant relationship on workplace harmony. Thus, it is recommended that institutional collaboration between management and employees, employee career enhancement as well leadership cooperation should be encouraged to attract workforce loyalty to the vision and mission of the state civil service.

Makinde (2013) carried out a study on securing a harmonious working environment through effective industrial relations at workplace: The Nigerian perspective The study was motivated by the need to 
create harmonious working environment void of strike actions in Nigeria. The study made use of primary data sourced from 220 respondents through administering of questionnaire. Their responses were tested using appropriate statistical tools like the simple percentage and the Chi-square research techniques; our study revealed that Harmonious Working Environment can be secured through Effective Industrial relations at workplace only that the challenges confronting the unions has not make their activities effective in a way. Therefore, the study recommended that organizations should create enabling environment for union activities to thrive by assisting them where necessary so as to stabilize the organization.

Nwokocha (2015) conducted a conceptual study on the title Employers and the Enhancement of Industrial Harmony in Private Sector Organizations in Nigeria. The study examines the role of employers in enhancing industrial harmony in organizations with a focus on private sector organizations in Nigeria. The paper posits that conflict is inevitable in all organizations and, as such, the employer who has the responsibility of making major organizational policies to achieve corporate objectives must play a dominant role in ensuring industrial harmony. The paper exposes some of the factors that undermine industrial harmony and productivity in private sector organizations to include leadership behaviour, lack of effective communication, work environment, and non-recognition of trade union as a bargaining party. It further explicates that productivity and growth are not fully enhanced because of management practice of exclusionism, poor labour-management policies, and dehumanization of work environment. As panacea to mitigate conflict and promote a culture of harmony that will achieve organizational goal, the study proposes that management of private sector organizations in Nigeria should fashion out a framework of joint committee/expanded collective bargaining, create work culture that is based on collaboration and team work, initiate participatory management and develop and restructure an effective communication process. Instituting these measures will help to close conflictual loopholes that hinder industrial harmony and productivity in private sector organizations in Nigeria.

Sholokwu and Olori (2016) investigated management practices and industrial harmony in oil and gas firms in Rivers State, Nigeria. The study examined the relationship between Management Practices and Industrial Harmony in the Oil and Gas Firms in Rivers State. Sample size of 343 were derived using Taro Yamane formula to from the population of 2400 respondents that consist of managers and employees in twelve oil and gas firms in Rivers State. Descriptive survey method of research was adopted and data were collected through questionnaire. The demographic data were analyzed using simple percentage and Mean score were used in the analysis of items on the questionnaire. The Spearman's Rank Correlation statistical method was used to test the seven hypotheses at 0.01 level of significance which was facilitated by Statistical package for Social Sciences (SPSS) software. The results revealed a significant relationship between Management practice and Industrial harmony. It was also found that organizational culture significantly moderates the relationship between managerial practices and industrial harmony in Oil and Gas Companies in Rivers State. Therefore, the study concludes that Management practice affects Industrial harmony in Oil and Gas Companies in Rivers State. Based on the findings, the study recommended that Oil and Gas Companies should embark on good management practices by implementing collective agreement, reducing casualisation of staff and to develop a promotion policy, to fewer incidences of strike and grievances to attain industrial harmony. However, this research is not exhaustive; hence, it suggests that future research should be carried out on the effect of Staff casualisation practices on industrial harmony in manufacturing firms in Rivers state.

Fejoh (2015) examined industrial democracy as determinant of job satisfaction among workers of Public Health Institutions in Ogun State, Nigeria. The study investigated industrial democracy as a determinant of job satisfaction among workers of public health institutions in Ogun State of Nigeria. The study employed the ex-post-facto research design. Questionnaire was administered to a purposely selected population of 100 staff of Olabisi Onabanjo University Teaching Hospital, Sagamu, Ogun State and State Hospital, Ijebu-Ode, Ogun State. Pearson moment correlation coefficient was used to test all the five hypotheses. The findings show that industrial democracy factors of information participation, consultative participation, associative participation, administrative participation and decisive participation have significant positive correlation with workers job satisfaction as follows - information participation( $\mathrm{r}=0.622, \mathrm{p}<0.005)$; consultative participation $(\mathrm{r}=0.800, \quad \mathrm{p}<0.05)$; associative participation $(\mathrm{r}=0.876, \mathrm{p}<0.005)$; administrative 
participation $(\mathrm{r}=0.818, \mathrm{p}<0.005)$ and decisive participation $(\mathrm{r}=0.809, \mathrm{p}<0.005)$. The study therefore recommended that managers of tertiary health institutions in Ogun State should develop a plat form where all cadres of workers will participate in the management of the institution and be updated with key happenings in the institutions as this will guarantee their satisfaction and higher productivity.

Akuh (2015) investigated industrial harmony for academic excellence: an imperative for a productive educational system in Nigeria. The objective of the study was to discuss the imperative of industrial harmony for academic excellence and a productive educational system in Nigeria. To ensure harmonious industrial relations, the leader of every institution will need to encourage, open and frank discussion of the institution's problems with the subordinates; seek the opinion of those doing the institutional job i.e. the staff; explain their discussion to those who have to carry them out; recognize the contributions of all involved in the institutional job; set collaborative goals to encourage team work instead of autocracy and listen to rather than talk at their subordinates. In conclusion, effective and understood grievance procedure that is simple, straightforward, flexible, proactive, responsive, devoid of protocol and time conscious is central to harmonious industrial relations. Above all, promoting visionary and disciplined leadership within our educational system is a key to a conductive environment for learning devoid of corrupt practices and indiscipline.

Osad and Osas (2013) investigated harmonious industrial relations as a panacea for ailing enterprises in Nigeria. The paper is aimed at studying whether harmonious industrial relations can be used as a panacea for organizational ailments especially that relating to human resources management. The method and techniques employed in collecting data and information for this study include critical summary of some existing literature and data collection (questionnaire and oral interview). The study concludes inter alia is that a harmonious industrial relation is indeed a most potent panacea for organization suffering from poor management, and that the support framework exists for the internalization as a management culture. The pivot is transaction theory and the theme is that collaboration will ensure positive change and team effort.

Akhaukwa, Maru and Byaruhang (2013) studied the effect of collective bargaining process on industrial relations environment in public universities in Kenya. The study found that academic staff felt that union and management did not cooperate well neither did they have mutual regard of each other nor were they willing to confer. Besides, management did not facilitated union's operation and its attitude to the union was not favorable. Hence, the industrial relations environment in the three public universities where the study was conducted was found to be poor. Academic staff were also discontented with the spirit of willingness to give and take, the degree of members' participation and feedback. The study further revealed that collective bargaining process had a significant effect on industrial relations environment in public universities in Kenya. Also, collective bargaining made a significant (and positive) contribution to industrial relations environment. This implies that a flawed process that is perceived to be unfair is likely to result in poor industrial relations environment and vice versa.

Mukoro (2013) investigated industrial harmony and staff performance in a school organization through effective communication. The study discusses effective communication, industrial or organizational harmony, the essence of communication, and the school manager and communication. The study also discusses how to use communication to improve both industrial harmony and staff performance. Finally, it recommends encouragement of constant bottom-up communication, in addition to top-down communication, to ensure that the views of subordinate staff are well understood and incorporated in decision-making.

Ememe (2014) examined public relations: as a tool of industrial harmony in Nigeria Police Headquarters Enugu. The objective of the study was to examine the internal and external problems of Nigeria police and how the police relations officer has succeeded or failed in resolving problems. To achieve this, survey research method was adopted with questionnaire as the instrument to elicit responses from the respondents. Findings drawn from the study revealed positive that police serving in Enugu faces internal and external problems such as poor salary, poor equipments at home and offices, insufficient accommodation, poor medical care and poor relationship with the publics; which makes it difficult for the police to manage crisis due to inadequate information from the publics. The study therefore recommended that police should stop extortion, bribery and corruption, brutality, aiding and abating crimes because of their position in the society. The publics should contribute 
positively to give vital information to the police to fight against crisis. The Police Public Relations Department should handle the internal and external problems through their cordial relationship with the press. Finally the government should take serious maintenance of the police in their welfare, so that they would take their work seriously.

Mayowa (2015) investigated Industrial conflict and its management in selected Nigerian manufacturing companies. This study examined industrial conflict and its management strategies in selected manufacturing companies in Lagos State, Nigeria. The study utilized co-relational survey method which involves the use of structured questionnaire and personal observation to elicit information from the respondents. Participants comprised of staffs of three manufacturing companies in Lagos, Nigeria. Multistage sampling technique was employed in selecting the respondents from the three manufacturing companies under the study. The data collected were analyzed using descriptive statistic including tables, frequency counts, and percentages as well as mean scores. The findings revealed that the causes of conflict in manufacturing companies in Lagos State, Nigeria include poor means of communicating grievances to top managers, unfavorable economic and industrial policies, poor employee compensation and welfare among others. Therefore, this study concluded that managers should combine strategies such as bargaining, collaboration and avoidance when dealing with industrial conflict to maintain cordial and productive labour-management relationship.

Tarela and Seth (2014) examined joint consultation and workers commitment in Nigerian Banking Industry. This study examined the relationship between Joint Consultation, a form of Employee Voice and Workers Commitment. Using Cross Sectional Survey design, a sample size of 357 workers from the banks in the South-South zone of Nigeria was used as respondents. The results drawn from the use of Spearman Rank Order Correlation showed that Joint Consultation had a significant positive association with workers affective commitment, but no significant association with workers continuance and normative commitment. The study found that with the use of Joint Consultation, workers are emotionally attached to their organizations and exhibits little continuance and normative commitment.

Genty (2014) examined leadership styles and their implications for prosperous industrial relations in Nigeria. The study examined how trade union leaders are going to survive in this turbulent economy paradigm using effective leadership styles that promote prosperous industrial relations in Nigeria. The study adopted discourse content analysis using secondary information of existing literatures on the subject matter to draw up a concrete conclusion with the aid of pictorial discussion. The study concluded that all the styles of leadership can enhance prosperous industrial relations but recommended the need for a situational approach to leadership. That is, the best style of leadership will depend upon the situation. Again, it is important to note that genuine leadership can only turn things around with the cooperation of followership. Therefore, a successful leader is the one which employs all forms of leadership styles in a given situation with predominate cooperation from its followership.

Odhong and Omolo (2014) analyzed factors affecting employee relations in organizations in Kenya, the case study of Waridi Ltd. Study variables included working conditions, communication, collective bargaining issues, recruitment and remuneration. The study adopted descriptive research design and a target population of 420. Stratified random sampling was done. Questionnaires were used to collect primary data. Qualitative and quantitative techniques of data analysis were employed. Based on the study findings, it is concluded that free communication and information flow is important in promoting employee relations. Collective bargaining provides the structure for clear job description and work performance. Overall, employee relation concepts such as employee trust, the manner in which employee complaints are dealt with, commitment to the organization, genuine social dialogue and existence of team spirit are fundamental in promoting good employee relations.

In all empirically reviewed literature, it appears that, none really considered employee loyalty, employee engagement and employee innovativeness as a dependent construct in relation to the joint consultation, industrial democracy and communication pattern as index for industrial harmony. Also, none of the works reviewed on industrial harmony and employee performance was carried out in food and beverage firm in Anambra State. All these are research gaps which this study will fill when completed. 
Industrial Harmony and Employee Performance in Food and Beverage Firms in Anambra State of Nigeria

\section{MeTHOdOLOGY}

Correlational Survey research design was adopted for this study because the study seek to determine the relationship between industrial Harmony and employee performance in selected Food and Beverage firms in Anambra State, Nigeria. The populations of the study are 390 employees of the five randomly selected Food and Beverage Firms in Anambra. These employees constitute of only the employee who do not have any managerial position in the organizations. The details are given as follow. The population of Eastern Distillers and Food Industries is 120 employee, Obisco Industries Ltd 80 employee, Jonabeth Distillers Industries Ltd 65 employee, Dozztephan Beverages Ltd 50 employee and Lwise Word Beverages Ltd has 75 employees. Questionnaire was used to collect relevant data for the study. The instrument of data collection was subjected to content validity. The study adopted Cronbach's alpha reliability technique and the result gotten was 0.859 which is above the 0.696 benchmark of acceptance of an instrument as reliable. Suwannoppharat and Kaewa-ard (2015) note that reliability coefficient of 0.696 and above is acceptable. Thus, the reliability coefficient of the instrument is considered satisfactory for the study. For data analysis, the researcher used aggregate scores and Pearson product moment correlation.

\section{Data Presentation And Analysis}

The table below shows the descriptive statistic of the extent industrial democracy relates with employee loyalty in selected Food and Beverage Firms in Anambra State. The mean values were used for the analysis and the acceptance region is 3.00 and above while the rejection region is below 3.00 .

Table1. Responses from the Respondents in the Questionnaire Distributed

\begin{tabular}{|c|c|c|c|}
\hline Questions & Questionnaire Items & Mean & Remark \\
\hline & Industrial Democracy & & \\
\hline 1 & $\begin{array}{l}\text { Employee are allow to participate in decision making process in matters } \\
\text { that relates to safety in my organization }\end{array}$ & 2.26 & Reject \\
\hline 2 & $\begin{array}{l}\text { Employee voice is heard and give positive response on issues of } \\
\text { employee safety in my organization }\end{array}$ & 2.38 & Reject \\
\hline 3 & $\begin{array}{l}\text { Management and employee meets regularly to discuss issues of } \\
\text { employee safety in workplace }\end{array}$ & 2.79 & Reject \\
\hline 4 & $\begin{array}{l}\text { I will be loyal to my organization if am allowed to participate in } \\
\text { decisions pertaining to safety in workplace }\end{array}$ & 3.39 & Accept \\
\hline \multirow[t]{2}{*}{5} & $\begin{array}{l}\text { My organization have suggestion box for taking suggestion on how to } \\
\text { improve workplace environment safety }\end{array}$ & 3.49 & Accept \\
\hline & Employee Loyalty & & \\
\hline 6 & $\begin{array}{l}\text { I will give this organization all my attention if the safety policy is } \\
\text { favourable to me }\end{array}$ & 3.58 & Accept \\
\hline 7 & $\begin{array}{l}\text { My undivided attention will be given to the organization if am involved } \\
\text { in making safety policy }\end{array}$ & 3.30 & Accept \\
\hline 8 & $\begin{array}{l}\text { If the safety police in my organization favour employee, I will not be } \\
\text { looking for another job }\end{array}$ & 4.83 & Accept \\
\hline 9 & I will loyal to the organization the safety policy favours the employee & 3.40 & Accept \\
\hline 10 & $\begin{array}{l}\text { I will remain faithful to my organization if employee voice is considered } \\
\text { in safety related matters }\end{array}$ & 3.84 & Accept \\
\hline
\end{tabular}

Source: Field Survey (2017)

\subsection{Hypothesis Testing}

There is a significant positive relationship between industrial democracy and employee loyalty.

Table2. Correlations Result

\begin{tabular}{|l|l|l|l|}
\hline \multicolumn{2}{|c|}{} & Industrial Democracy & \multicolumn{1}{c|}{ Employee Loyalty } \\
\hline \multirow{3}{*}{$\begin{array}{l}\text { Industrial } \\
\text { Democracy }\end{array}$} & Pearson Correlation & 1 & $.892^{* * *}$ \\
\cline { 2 - 4 } & Sig. (2-tailed) & & .000 \\
\cline { 2 - 4 } & $\mathrm{N}$ & 372 & 372 \\
\hline \multirow{2}{*}{$\begin{array}{l}\text { Employee } \\
\text { Loyalty }\end{array}$} & Pearson Correlation & $.892^{* *}$ & 1 \\
\cline { 2 - 4 } & Sig. (2-tailed) & .000 & 372 \\
\cline { 2 - 4 } & $\mathrm{N}$ & 372 & \\
\hline
\end{tabular}

**. Correlation is significant at the 0.01 level (2-tailed).Field survey, 2017 


$$
\begin{aligned}
& \text { Test of Significance } \\
& \begin{aligned}
\mathrm{t}= & \frac{r \sqrt{N-2}}{\sqrt{1-r^{2}}} \\
\mathrm{t} & =\frac{0.892 \sqrt{372-2}}{\sqrt{1-0.892^{2}}} \\
\mathrm{t} & =\frac{0.892 \sqrt{370}}{\sqrt{1-0.892^{2}}} \\
\mathrm{t} & =\frac{0.892 \times 19.24}{\sqrt{1-0.796}} \\
\mathrm{t} & =\frac{17.16}{0.452} \\
\mathrm{t} & =3.80
\end{aligned}
\end{aligned}
$$

From the analysis in table 4.2.30 which shows the result of the hypothesis test, it revealed that there is a very strong positive relationship between industrial democracy and employee loyalty. as typified by the correlation coefficient of 0.892 . When the significance of the relationship was tested, the result showed that $\mathrm{t}_{\text {cal }}=3.80$ was greater than $\mathrm{t}_{\text {crit. }}=2.576$ at $5 \%$ significance level $(\alpha=0.05)$ and $(\mathrm{n}-2)$ degree of freedom. Hence, since $t_{\text {cal }}=3.8$ was greater than $t_{\text {crit. }}=2.576$, the null hypothesis is rejected. This was substantiated by the score of the p-value $(0.000)$ is less than the significant level $(0.05)$ at 2-tailed test.

\section{DISCUSSION OF FINDINGS AND CONCLUSION}

From the result of the test of hypothesis two, it was revealed that there is a very strong positive relationship between Industrial Democracy and Employee Loyalty as shown by the correlation coefficient of 0.892 and it is significant because the p-value (0.000) is less than the significant level $(0.05)$ at 2-tailed test. Therefore the null hypothesis is rejected and accept the hypothesis which states that, there is a significant positive relationship between industrial democracy and employee loyalty. This is in consonance with the study of Fejoh (2015) Researched Industrial Democracy as Determinant of Job Satisfaction among Workers of Public Health Institutions in Ogun State, Nigeria. The study investigated industrial democracy as a determinant of job satisfaction among workers of public health institutions in Ogun State of Nigeria. The findings show that industrial democracy factors of information participation, consultative participation, associative participation, administrative participation and decisive participation have significant positive correlation with workers job satisfaction.

From the result of the test of hypothesis two, it was revealed that there is a very strong positive relationship between Industrial Democracy and Employee Loyalty as shown by the correlation coefficient of 0.892 and statistically significant with a value of 0.0000 .

From the findings of the study, the study concludes that industrial harmony plays a crucial role in determining employee performance in selected Food and Beverage Firms in Anambra State. It also tells how satisfied employees will be with their jobs and their engagement to the organization and their innovativeness in the organization could also be predicted from in an harmonious work environment.

\subsection{Recommendations}

Based on the findings of the study, the study made the following recommendations:

- Management of the focused firms should give room for unions in the organization to air their views and try as much as possible to align the needs of the employees to that of the firm.

- The management of the focused firms should create an atmosphere of feeling of belonging by allowing the employee participates in decision making on matters that relate to them. 


\section{REFERENCES}

[1] Adejumo, B. A. (2007). "The Role of the Judiciary in Industrial Harmony." Being commentary delivered at 2007 All Nigeria Judges' Conference Organized by The National Judicial Instituteat LadiKwali Hall of the Abuja Sheraton Hotel and Towers, Abuja, FCT.

[2] Adejumo, B. A. (2009). "Effect of Industrial Disputes Resolution on Investment in Africa". Being paper Delivered at Lagoon Restaurant Organised by: National Conflict Mediation Group on President of the National Industrial Court. By Hon. Justice Babatunde Adeniran Adejumo (OFR).

[3] Adejumo, B. A. (2010). NIC and Harmony in Universities. Retrieved from news.onlinenigeria.com/ .../22021-nic-and-nic-harmony-in-universities

[4] Adejumo, B. A. (2011). "The National Industrial Court Of Nigeria:" Past, Present and Future. Being A Paper Delivered At The Refresher Course Organised For Judicial Officers Of Between 3-5 Years Post

[5] Armstrong, N. (2005). A Hand Book of Human Resource Management Practice. London: Kogan Page Limited

[6] Agba, A.M.O, Ushie. E.M; \& Agba, M.S. (2009). "External Factors in Industrial Crisis in the Nigeria" Service. Nigerian Journal of Labour and Industrial Relations, 3(3), 75-94

[7] Appointment By The National Judicial Institute, Abuja At The Otutu Obaseki Auditorium, National Judicial Institute.

[8] Adejumo, B. A. (2013). Inaugural speech by President of National Industrial Court of Nigeria at the Inaugural siting of the Makurdi Division of the Court on 4th of February, 2013 at Makurdi, Benue State, Nigeria

[9] Akintayo M.O. (1985), "Industrial Democracy and Labour-Management Relations in Nigeria". The Nigerian Journal of Industrial Education and LabourRelations.2(1).

[10] Akintayo M.O. (1992). Perspective in Industrial Relations: An introduction. Handbook, Unpublished, Ibadan: University of Ibadan, Nigeria.

[11] Akpoyovwaire, S.M. (2013). "Improving Industrial Harmony and Staff Performance in a School Organization" through Effective Communication. International Journal of Scientific Research in Education, 6(3), 263-270.

[12] Akuh, E.A. (2015). "Industrial harmony for academic excellence: an imperative for a productive educational system in Nigeria." European Journal of Educational and Development Psychology Vol.3, No.4, pp.36-44.

[13] Bassey, A. O., Ojua, T. A., Archibong, E. P., \& Bassey, U. A. (2012). "The Impact of Inter Union Conflicts on Industrial Harmony:" The Case of Tertiary Institution in Cross River State. Nigeria, Malayasian Journal of Society and Space, 8(4), 33-39.

[14] Clegg, H. (1960). A New Approach to Industrial Democracy. Oxford: Blackwell Publishers.

[15] Donnelly J, Gibson J, Ivancevich J (1984) Fundamentals of management. Business Publications Inc., Texas

[16] Eno, V (1996) Public personnel management. Unpublished Monograph. University of Uyo, Uyo.

[17] Eserinune Mccarty Mojaye, E.M. \& Dedekuma, S.E. (2015) conducted a study on the Influence of Communication on Industrial Harmony in the Civil Service of Delta State Nigeria. New Media and Mass Communication. ISSN 2224-3267 Vol.37, 2015

[18] Ememe, I.N. (2014). Public relations: as a tool of industrial harmony (A Study Of Nigeria Police Headquarters Enugu). A Research Project Submitted To The Department Of Mass Communication Faculty Of Management And Social Sciences Caritas University, Amorji-Nike, Enugu.

[19] Fajana, S. (2000). Industrial Relations in Nigeria: Theory and Features. Lagos: Labofin and Company.

[20] Fejoh, J. (2015). "Industrial Democracy as Determinant of Job Satisfaction among Workers of Public Health Institutions in Ogun State, Nigeria". International Journal of Humanities and Social Science Vol. 5, No. 10

[21] Genty, K. I. (2014). "Leadership Styles And Their Implications For Prosperous Industrial Relations In Nigeria". European Scientific Journal February 2014 /SPECIAL/ edition vol.1 ISSN: 1857 - 7881.

[22] Hanson J (1972) "Economics. Macdonald and Evans Limited," London International Journal of Multidisciplinary Educational Research, 1(1), 146 - 151.

[23] Johnson, T.W.\& Stinson, J.E. (1978). Management Today and Tomorrow. New York: Harper and Row Publishers Inc.

[24] Korsch, K. (1922). Arbeisrecht fur Betriebsrate. Frankfurt/M: Europaische Velangsanstalt

[25] Laosebikan, D. (1995). Incidence of Trade Disputes in First Bank of Nigeria Plc; The LabourManagement Relations. M.Ed. Dissertation, Unpublished, Ibadan: University of Ibadan, Nigeria 
Industrial Harmony and Employee Performance in Food and Beverage Firms in Anambra State of Nigeria

[26] Nkiinebari, N.P. (2014). "Workplace Democracy and Industrial Harmony in Nigeria". international journal of innovative research \& development. Vol 3 Issue 1

[27] Nkiinebari, N.P. (2015). "Employee Engagement and Workplace Harmony in Nigeria Civil Service". international journal of innovative research \& development. Vol 4 Issue 2

[28] Nwokocha, I. (2015). "Employers and the Enhancement of Industrial Harmony in Private Sector Organizations in Nigeria". IOSR Journal of Humanities and Social Science. Volume 20, Issue 5, Ver. II (May. 2015), PP 28-35 e-ISSN: 2279-0837, p-ISSN: 2279-0845

[29] Makinde, H.O. (2013). "Securing a harmonious working environment through effective industrial relations at workplace": The Nigerian perspective Business Management Dynamics Vol.3, No.2, Aug 2013, pp.46-59.

[30] Muller-Jentsch, W. (2008).'Industrial Democracy: Historical development and current challenges". Management Review, 19(4):260-273.

[31] Mukoro, S.A. (2013).’'Improving Industrial Harmony and Staff Performance in a School Organization through Effective Communication". International Journal of Scientific Research in Education, SEPTEMBER 2013, Vol. 6(3), 263-270.

[32] Mayowa, S.O. (2015). "Industrial conflict and its management in selected Nigerian manufacturing companies". International Journal of Organizational Leadership 4(2015)

[33] Mojaye, E.M \& Dedekuma, S.E (2015). "Influence of Communication on Industrial Harmony in the Civil Service of Delta State Nigeria". New Media and Mass Communication ISSN 2224- 3267 (Paper) ISSN 2224-3275 (Online) Vol.37, 2015

[34] Nwinyokpugi P. N.(2014) "Workplace Democracy And Industrial Harmony In Nigeria”, International Journal Of Innovative Research \& Development. Vol 3 Issue 1

[35] Otobo, D. (2005). Industrial Relations: Theory and Controversies. Lagos: Malhhouse Press Ltd.

[36] Okon, B.A., Asu, O,T., Patrick, A.E. \& Antigh, B.U. (2012)The impact of inter-union conflicts on industrial harmony: The case of tertiary health institutions in Cross River State, Nigeria

[37] Odia, L.O. and Omofonmwan S.I. (2007). Educational system in Nigeria: problems and prospects. Journal of social Sciences. 14(1): 81-86.

[38] Ogunyemi, K.A.A. (1998). The Extent of Industrial Democracy in the Nigeria Banking Industry: A case study of First Bank of Nigeria Ltd, Ibadan Zone. M.Ed. Dissertation, Unpublished, Ibadan: University of Ibadan, Nigeria.

[39] Puttapalli, A.K. and Vuram, I.R. (2012). Discipline: The tool for industrial harmony

[40] Puttapalli, A.K. and Vuram, I.R. (2012). Discipline: The tool for industrial harmony.

[41] Poole, M. (1992).Industrial Democracy. In Georgy Szell (ed.): Concise Encyclopedia of Participation and Co-Management. Berlin and New York: De Gruyter: 429-43

[42] Sholokwu, B. M. \& Olori, W.O.(2016). Management Practices And Industrial Harmony In Oil And Gas Firms In Rivers State, Nigeria. International Journal of Advanced Academic Research | Social \& Management Sciences | ISSN: 2488-9849 Vol. 2, Issue 11..

[43] Sayles L, Straus G (1981) Managing human resources. Prentice Hall Inc., New Jersey.

[44] Tarela, O. \& Seth, A.J. (2014). Joint Consultation and Workers Commitment in Nigerian Banking Industry. International Journal of Business and Management; Vol. 9, No. 3; 2014 ISSN 1833-3850 E-ISSN 1833-8119

[45] Osad, O.I. \& Osas, U.E. (2013). Harmonious industrial relations as a panacea for ailing enterprises in Nigeria. Journal of Asian Scientific Research, 2013, 3(3):229-246

[46] Ukonu, O.I \& Gideon A. E. (2016). The role of national industrial court in sustaining harmony in nigerian health sector: a case of university of abuja teaching hospital. Journal of Management and Sustainability; Vol. 6, No. 1 .

\section{AUTHOR'S BIOGRAPHY}

Dr Chinedu Uzochukwu is a Senior Lecturer in the Department of Business Administration, Nnamdi Azikiwe University Awka, Nigeria. He is currently the Deputy Director of Unizik Business School of the same University.

Dr Vincent Aghara is a Senior Lecturer in the Department of Marketing, Nnamdi Azikiwe University Awka, Nigeria. He was the Head, Department of Marketing of the same University.

Dr Stella Enaini Olohi is a Lecturer in the Department of Business Administration, Auchi Federal Polytechnic Auchi, Edo State, Nigeria, an affiliate of Nnamdi Azikiwe Univetsity Awka for Degree Programme, She is currently the coordinator of the programme in the Department. 
Industrial Harmony and Employee Performance in Food and Beverage Firms in Anambra State of Nigeria

Perpetual Abaniwu is a postgraduate student in the Department of Business Administration, Nnamdi Azikiwe University Awka, Nigeria

Citation: Dr. Chinedu Uzochukwu Onyeizugbe, et.al. “ Industrial Harmony and Employee Performance in Food and Beverage Firms in Anambra State of Nigeria" International Journal of Managerial Studies and Research (IJMSR), vol 6, no. 6, 2018, pp. 22-35. doi:http://dx.doi.org/10.20431/2349-0349.0606004.

Copyright: () 2018 Authors. This is an open-access article distributed under the terms of the Creative Commons Attribution License, which permits unrestricted use, distribution, and reproduction in any medium, provided the original author and source are credited. 